\title{
Design and References of the Staged Air High Momentum Burner
}

\author{
Peter Horbaj* , Peter Lukáč
}

\author{
Technical university of Košice, Faculty of Mechanical Engineering, Department of Power Engineering, Vysokoškolská 4, 04200 Košice, Slovak \\ Republik
}

\section{BIOGRAPHICAL NOTES}

prof. Ing. Peter Horbaj, CSc. , is a professor at Department of Power Engineering, Faculty of Mechanical Engineering, Technical University of Košice. He is an author and coauthor of 7 textbooks, co-author of 1 patent and an author/co-author of 305 papers published in various local and international journals. He has presented results of his work on various international conferences. His research and project assignments focus on energy utilization of waste treatment, impulse burners, biogas stations, utilization of wood chips. He has been awarded several prizes.

Ing. Peter Lukáč, PhD. , is a graduate of Thermal Power Engineering from Faculty of Metallurgy, Technical University of Košice. He currently works as a senior assistant professor at Department of Power Engineering, Faculty of Mechanical Engineering of TU of Košice. He takes part in solving research assignments, grants and projects at the department and the university. His research interest includes heat supply, compressors, pumps, combustion devices, cooling equipment and heat pumps. He is an author of over 50 original manuscripts published in local and international journals; conference papers and 4 university textbooks. He is a member of the Editorial Board of Gas-WaterHeating-Air-conditioning Journal.

\section{KEY WORDS}

Burner, high momentum burner, combustion, $\mathrm{NO}_{x}$ emission.

\section{ABSTRACT}

The results of experimental investigations of the gas fired two-staged burner of air high momentum are presented in this paper. It was carried out in order to study the operating parameters and the effects of the change of excess air as well as the addition of water into the pre-heated combustion air stream on the $\mathrm{NO}_{x}$ emission.

\section{Introduction}

The combustion products, formed as a result of combustion of fuel, are accelerated to high outlet velocities (according to reference [1]: from 50 to 500 m.s-1) in a high momentum burner. In comparison to the conventional atmosphere burners, the high momentum burners have the following advantages:

- higher heat transfer by convention,

- higher heating rate,

more uniform temperature and concentration fields in the working space of the furnace.

In practice, these burners can be used either to intensify the convection heat transfer by direct orientation of the combustion products to the charge, i.e. in the so-called rapid heating case, or to obtain the high uniform temperature and concentration fields in the combustion chamber by intensive internal recirculation of the combus- 
tion products. Actually, both these possibilities are closely associated and are usually utilised together.

It is well known that the change of excess air, i.e. oxygen, in the reaction zone of combustion process has significant influence on $\mathrm{NO}_{x}$ formation. In order to reduce $\mathrm{NO}_{x}$ formation in the gas fired two-stage air high momentum burner considered in this paper, the method of water or steam addition into air or natural gas stream can be applied in addition to the air- staging technique. Due to this reason, the following aims of experimental investigations in this study were set:

\section{- To find out the burner's operating parameters,}

- To find out the influence of air excess on $N O_{x}$ formation,

- To compare the investigation results with the values calculated by using the existing mathematical models of $\mathrm{NO}_{x}$ formation,

- To find out the influence of water addition into pre-heating air stream on NOx formation.

\section{Design of the High Momentum Burner}

The two-stage air high momentum burner, which was designed and patented by author, is shown in figure 1 [2]. The fuel inlet (14) is located on the central axis of burner and the primary combustion air enters the burner through the entry slot (7) placed tangentially and it makes the formation of homogenous fuel mixture possible. The secondary combustion air enters the front header (2) circularly through slot (11). Owing to the circular flow, the baffle passage (10) and the angle of six inlet pipes (5) of $35^{\circ}$ measured from axial direction, the distribution of velocity, temperature and concentration are more uniform throughout the combustion chamber and the mixing of reactants is also better. The head of burner (9) is made of refractory material (4). The case of the burner's head, the front header and the body of burner (6) are made of $1.5 \mathrm{~mm}$ steel plate. The outlet part of the burner is constricted into a nozzle (8) to obtain a high exit velocity of combustion products.

The point is first to take advantage of both, the good stability and low $\mathrm{NO}_{x}$ emissions associated with rich combustion and, subsequently, to complete the combustion of the unburned $\mathrm{CO}$ and $\mathrm{H}_{2}$ in a lean stage where additional $\mathrm{NO}_{x}$ production is also low. For the staging to be effective, the mixing of rich products and air must be very rapid.

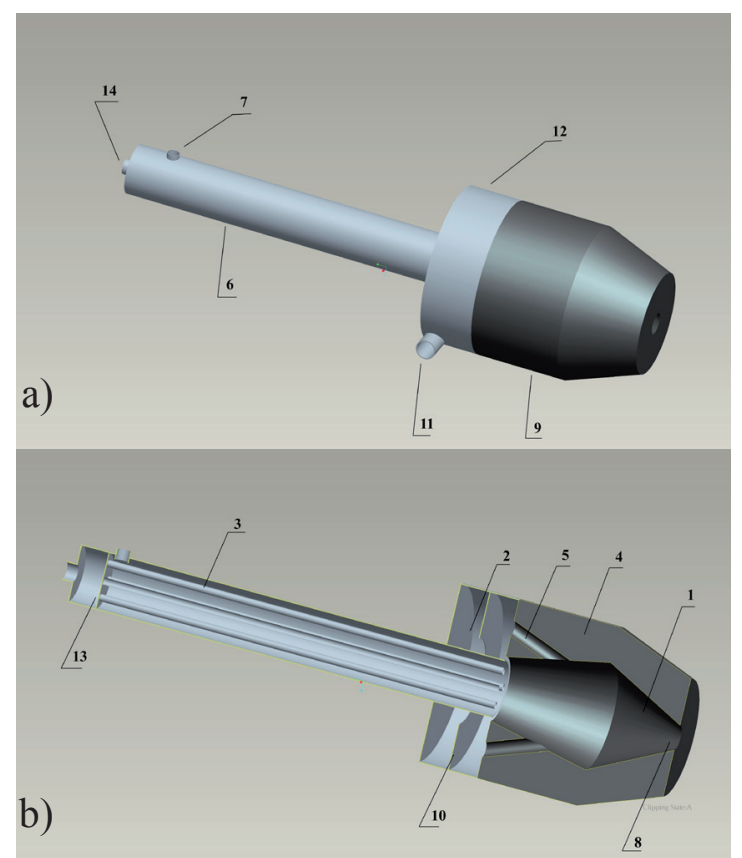

Fig. 1: (a) A design of a two-staged air high momentum burner (b) A cross section of the burner.

\subsection{Burner test facility}

3. Measurements

All measurements were performed using the experimental facility shown in figure 2. The facility was designed in the laboratory of the Faculty of Metallurgy of the Technical University of Košice in such a way that the mounting and testing of different burner types was enabled. It mainly consists of devices suitable only for measurement of the gaseous fuel, the combustion air and the flue gases.

The combustion air (2) is supplied by three electric fans connected in series. The air flow rate is measured using rotometers, (6) and (6a). The pressure is measured by manometers (3) and (3a). The temperature of pre-heated air is measured by a thermometer (5). The regulating valves (4), (4a), (7) and (7a), used for the air flow rate control and maintaining the constant pressure are placed in front of the rotometers. The by-pass line (8) may be used for the maximum air flow rate when the measuring scale of rotometer is insufficient. The air pressure in the area in front of burners is measured by manometers (9) and (10).

In two-stage air high momentum burner, the primary combustion air was led through the inlet part to the gas- meter (19) and the secondary 
one was led to the burner through the turbine gas- meter (21) by an electric fan (20). The gaseous fuel is supplied by a fan (1) through a valve (18), a gas-meter (17), a rotating suction device (16) and a balance vessel (14). The fuel flow rate is controlled by the regulating valves, (13) and (15). The fuel pressure and inlet air are measured by manometers. The conventional suction method using water cooled stainless steel probe was used for measuring concentration. Concentration of $\mathrm{CO}, \mathrm{CO}_{2}$ and $\mathrm{O}_{2}$ in flue gases is analysed using the VEB Junkalor analyser and concentration of $\mathrm{NO}_{x}$ is done by the TESTO 32, Testotherm analyser [3]. The gas sample must be cooled down to the ambient temperature because the $\mathrm{NO}$ gases gradually oxidise to form $\mathrm{NO}_{2}$ gases without being cooled [4].

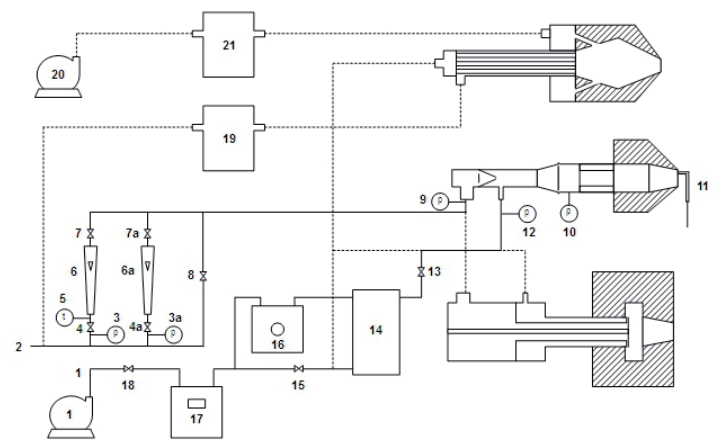

Fig. 2: Scheme of a burner test facility.

\subsection{Thermal NO formation Carvalho's model}

Thermal NO is formed from atmospheric nitrogen according to the extended Zeldovich mechanism that comprises the following steps [5]:

$$
\begin{aligned}
& O+N_{2} \Leftrightarrow N O+N \\
& N+O_{2} \Leftrightarrow N O+O \\
& N+O H \Leftrightarrow N O+H
\end{aligned}
$$

The steady state approximation for the nitrogen atom concentration yields:

$$
\begin{aligned}
& \frac{\mathrm{d}[\mathrm{NO}]}{\mathrm{d} \ddot{\mathrm{A}}}=\frac{1}{1+\frac{\mathrm{K}_{1} \cdot[\mathrm{NO}]}{\mathrm{K}_{2} \cdot\left[\mathrm{O}_{2}\right]+\mathrm{K}_{3} \cdot[\mathrm{OH}]}} . \\
& {\left[\begin{array}{l}
2 \cdot \mathrm{K}_{1} \cdot\left[\mathrm{N}_{2}\right] \cdot[\mathrm{O}]-\frac{2 \cdot \mathrm{K}_{-1} \cdot \mathrm{K}_{-2} \cdot[\mathrm{NO}]^{2} \cdot[\mathrm{O}]}{\mathrm{K}_{2} \cdot\left[\mathrm{O}_{2}\right]+\mathrm{K}_{3} \cdot[\mathrm{OH}]} \\
-\frac{2 \cdot \mathrm{K}_{-1} \cdot \mathrm{K}_{-3} \cdot[\mathrm{NO}]^{2} \cdot[\mathrm{H}]}{\mathrm{K}_{2} \cdot\left[\mathrm{O}_{2}\right]+\mathrm{K}_{3} \cdot[\mathrm{OH}]} \\
\left(\mathrm{mol} \cdot \mathrm{cm}^{-3} \cdot \mathrm{s}^{-1}\right)
\end{array}\right]}
\end{aligned}
$$

where :

- $[\mathrm{NO}],[\mathrm{O}],\left[\mathrm{O}_{2}\right],[\mathrm{OH}],[\mathrm{H}]$ all concentrations have units of $\left(\mathrm{mol} . \mathrm{cm}^{-3}\right)$,

- $K_{3}-K_{4}-K_{5}-K_{-3}-K_{-4}$ and $K_{-5}$ all forward and reverse rate constants of reactions (I), (2) and (3) have units of $\left(\mathrm{cm}^{3} \cdot \mathrm{mol}^{-1} \cdot \mathrm{s}^{-1}\right)$.

Assuming that the reaction:

$\mathrm{O}+\mathrm{OH} \Leftrightarrow \mathrm{O}_{2}+\mathrm{H}$

is in partial equilibrium, we have:

$$
[\mathrm{H}]=\frac{\mathrm{K}_{-2} \cdot \mathrm{K}_{3} \cdot[\mathrm{O}] \cdot[\mathrm{OH}]}{\mathrm{K}_{2} \cdot \mathrm{K}_{-3} \cdot\left[\mathrm{O}_{2}\right]}\left(\text { mol } \mathrm{cm}^{-3}\right)
$$

After substitution of this relation in (4) and also after simplification when $[\mathrm{OH}]$ concentration is very small, as in most lean flames (neglecting reaction (3)) :

$$
\begin{aligned}
& \frac{\mathrm{d}[\mathrm{NO}]}{\mathrm{d} \ddot{\mathrm{A}}}= \\
& =\frac{2 \cdot[\mathrm{O}] \cdot\left(\mathrm{K}_{1} \cdot \mathrm{K}_{2}\left[\mathrm{O}_{2}\right] \cdot\left[\mathrm{N}_{2}\right]-\mathrm{K}_{-1} \cdot \mathrm{K}_{-2} \cdot\left[\mathrm{NO}^{2}\right)\right.}{\mathrm{K}_{2} \cdot\left[\mathrm{O}_{2}\right]+\mathrm{K}_{-1} \cdot[\mathrm{NO}]} \\
& \quad\left(\mathrm{mol} \cdot \mathrm{cm}^{-3} \cdot \mathrm{s}^{-1}\right)(7)
\end{aligned}
$$

Table 1: The forward and reverse rate constants of reactions

\begin{tabular}{|l|l|}
\hline Constant & $\mathrm{K}\left(\mathrm{cm}^{3} \cdot \mathrm{mol}^{-1} \cdot \mathrm{s}^{-1}\right)$ \\
\hline $\mathrm{K} 1$ & $1.36 \cdot 10^{14} \cdot \mathrm{e}^{\frac{-75400}{\mathrm{R}} \cdot T}$ \\
\hline $\mathrm{K} 2$ & $6.43 \cdot 10^{9} \cdot T \cdot \mathrm{e}^{\frac{-6250}{\mathrm{R} \cdot T}}$ \\
\hline $\mathrm{K}_{-1}$ & $3.1 \cdot 10^{13} \cdot \mathrm{e}^{\frac{-334}{\mathrm{R} \cdot T}}$ \\
\hline $\mathrm{K}_{-2}$ & $1.55 \cdot 10^{9} \cdot T \cdot \mathrm{e}^{\frac{-38640}{\mathrm{R} \cdot T}}$ \\
\hline
\end{tabular}

\subsection{Experimental results}

The inlet charging of natural gas was $6.5 \mathrm{~m}^{3} \cdot \mathrm{h}^{-1}$, which corresponds to the thermal load of combustion chamber of $2.33 .10^{7} \mathrm{~W} / \mathrm{m}^{3}$, during the measurements and the velocity of outlet combustion gas flow was $265 \mathrm{~m} . \mathrm{s}^{-1}$ (calculated according to the combustion gas temperature of $1600^{\circ} \mathrm{C}$ and the excess air ratio of 1.02).

In order to investigate the influence of excess air on $\mathrm{NO}_{x}$ emissions, experiments were performed by varying the stoichiometry parameters, i.e. air-fuel ratio. The effect of varying the excess air ratio on the $\mathrm{NO}_{x}$ formation is shown in figure 3 . The results show that $\mathrm{NO}_{x}$ emissions reach extreme values in the range of air excess $1.07<n<1.2$. The best cor- 
relation between the $\mathrm{NO}_{x}$ emissions and the excess air derived on the basis of experimental results in the form of polynomial regression, which is given by the following equation, in the validity range of air-fuel ratio $1.008<\mathrm{n}<1.5$ :

$$
\begin{aligned}
& {\left[N O_{x}\right]=0.577 n^{3}-2.193 n^{2}+} \\
& +2.72 n-1.089(\text { Vol. \% })
\end{aligned}
$$

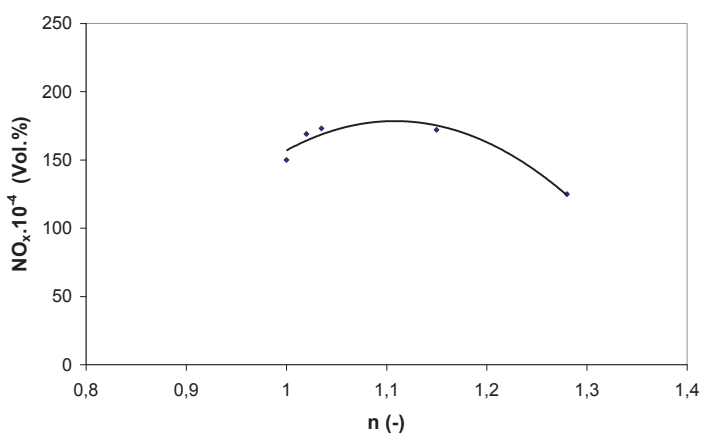

Fig. 3: Effects of air excess on NOx emissions obtained by experiments.

At the same time the values of $\mathrm{NOx}$ formation are calculated on the basis of following mathematical models: the Zeldovich, the Hung, the Boschan and the Carvalho models [5]. It was established that the Carvalho's model corresponds to the measurement values better than the other above-mentioned models. The effects of varying the excess air ratio on the $\mathrm{NO}_{x}$ emission in the burner process according to the Carvalho's model are plotted in figure 4.

The other results of experimental investigations

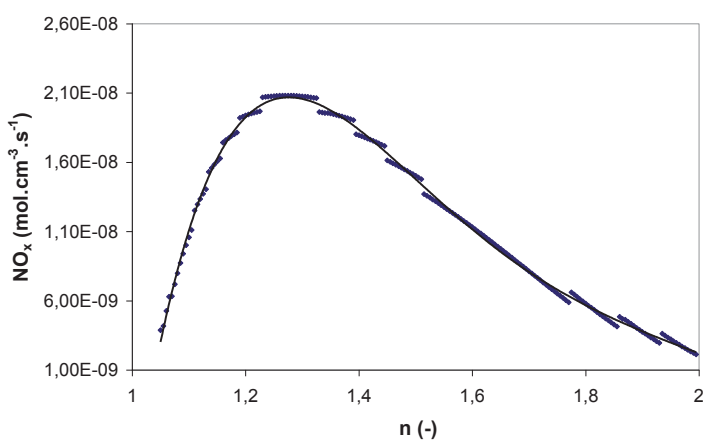

Fig. 4: Effects of air excess on NOx emissions determined by the Carvalho's model. of the two-stage gas-fired burner of air high momentum are presented in figure 5. The $\mathrm{NO}_{x}$ emissions decrease by over 50\% with the excess air coefficient decrease to the value of $n=0.5$ in the primary combustion mixture results from the figure.

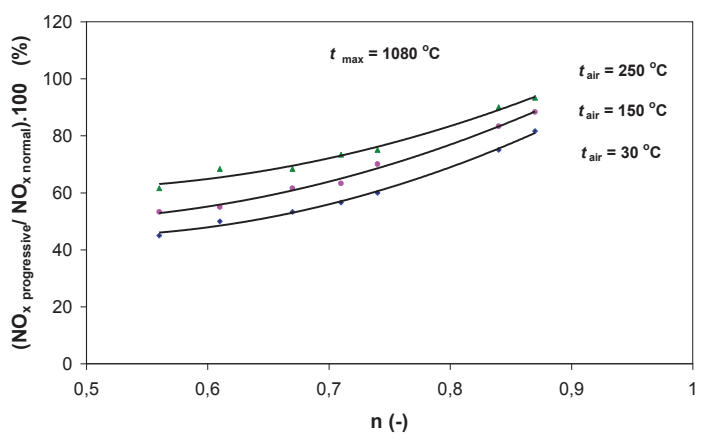

Fig. 5: The degree of $N \mathrm{O}_{x}$ reduction depending on the excess air in the primary combustion mixture.

The investigation results of the tests studying the effects of water addition into the combustion air stream on the $\mathrm{NO}_{x}$ formation are given in fig. 6 . Up to $50 \mathrm{~g} . \mathrm{m}^{-3}$ of water was gradually added into the stream of pre-heated air $\left(300-400^{\circ} \mathrm{C}\right)$. It results from the shown curve that with each $50 \mathrm{~g}$ of added water the $\mathrm{NO}_{x}$ emissions are reduced by about 50\%. This technology has been developed to reduce temperature peaks in oxygen-rich part of the flame. Injecting water reduces flame temperatures because combustion energy is used to vaporise and superheat the water to the combustion temperatures. In concept, water injection is the same as flue gas recirculation and both act as diluents. These temperature reduction techniques have their effects primarily on formation of thermal $\mathrm{NO}$ x products.

In addition, water vapour has the catalytic effect. The atomic oxygen reacts primarily with the carbon and then with the carbon monoxide, and amply with the nitrogen in gaseous hydrocarbon combustion. Accordingly, the concentration of $\mathrm{O}$ atoms has the significant role in the NO formation. During this process, the molecular hydrogen works as an efficient catalyst for the reduction of $\mathrm{NO}$ to $\mathrm{N}$ [6] [7]:

$2 \mathrm{NO}+2 \mathrm{H}_{2} \Leftrightarrow \mathrm{N}_{2}+2 \mathrm{H}_{2} \mathrm{O}$ 


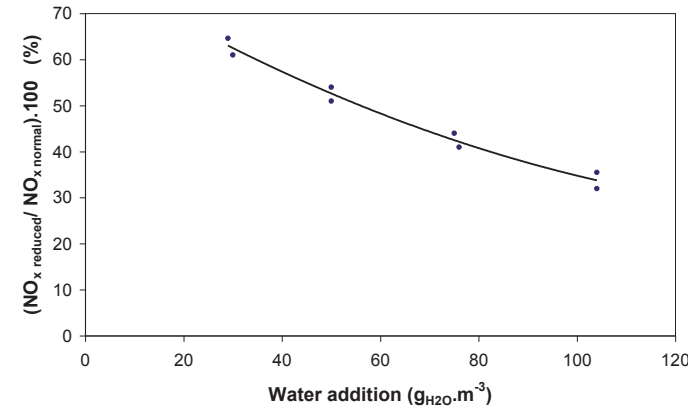

Fig. 6: Influence of adding water on $\mathrm{NO}_{x}$ emissions at $n=1.05$ and $t_{\max }=1300^{\circ} \mathrm{C}$.

\section{Conclusions}

On the basis of experimental results, the following operating characteristics of the gas fired twostage air high momentum burner are obtained:

- Input fuel control ratio is 1: 20, i.e. the minimum input fuel is $5 \%$ of the nominal input fuel,

- Flame stability is in the firing range of air-fuel ratio $0.5<n<-3$,

- The ratio between primary and secondary combustion air may be in the ratio of 1:1 to 3:1, e.i. the burner works without noise or vibration, in the range of $1.01<n<1.06$,

- The considered burner has succeeded in lowering $N O_{x}$ emission to the level below limit values of the EEC countries' regulations without using any special techniques. It was due to the staged air combustion. The combustion air is mixed with the fuel at different points. Since the heat is realised more uniformly throughout the combustion chamber, the NOx formation decreased notably,

- It is also possible to reduce the NOx emission by adding water to the air combustion stream.

\section{References}

[1] Günter, R.: Verbrennung und Feuerungen, Springer-verlag, Berlin, 1974.

[2] Gál, J., Panevský, N., Horbaj, P.: Vysokorýchlostný horák na plynné palivá s dvojstupňovým prívodom spalovacieho vzduchu, Autorské osvedčenie AO 0231359, Urad pre patenty, Praha, 1987

[3] Horbaj, P.: Ekologické aspekty spal'ovania palív v hutníckych a priemyselných agregátoch, Habilitačná práca, HF TU Košice, 1996.

[4] Gál, J. et al.: Vývoj bezpulzačných impulzných horákov na plynné palivá, Výskumná správa, HFVŠT Košice, 1975.

[5] Lazič, L., Horbaj, P.: Mathematical model of nitrogen oxide generation, Proceedings 39th annual conference KoREMA, Zagreb, 1994.

[6] Woperané, S., A.: S02 és NOx emisszió csékkentése, Ethnica, Debrecén, 1961.

[7] Čarnogurská, M., Schwarzbacherová, E.: The mathematical model by production
NOx by combustion process of natural gas with recirculation. Acta Mechanica Slovaca. Vol. 6, No. 2, 2002, p. 519-524. ISSN 1335-2393

[8] Lazič, L., Lukáč, L., Lukáč, P., Hršak, D.: Influence of the external recirculation of flue gas on reduction of NOX at propane butane combustion. Journal of International Scientific Publications: Ecology \& Safety, Vol. 5, Part 2, 2011. p.4 - 16. ISSN 1313 $-2563$

[9] Lukáč, L., Dolináková, A., Suchý, T.: Analýza primárnych metód na znižovanie emisií NOx. Acta Mechanica Slovaca. Vol. 8, No. 3-d, 2004, p. 719-724. ISSN 13352393

[10] Nekvasil, R., Neterda, Z:: Influence of media mixing rates in T-joints upon their damage. Applied and Computational Mechanics, Vol. 1, No.1, 2007, p.571 - 576. ISSN 1802-680X.

[11] Bigoš, P: Dynamical strenght and durability of machine parts. Acta Mechanica Slovaca. Vol. 10, №. 4-B, Optimalizácia mechanických sústav a zariadení, 2006, p. 61-72. ISSN 1335-2393120

[12] Mikielewicz, D., Andrzejczyk, R., Klugmann, K.: Experimental investigations on condensation in flow of HFE - 7100 in small diameter channels. 14th International Symposium „Heat Transfer and Renewable Sources of Energy“, Szzzecin Międzyzdroje, September 6-9, 2012, Poland

[13] Blejchař, T., Dolníčková, D.: Numerical simulation of SNCR technology with simplified chemical kinetics model In: EPJ Web of Conferences : vol. 45 : EFM 2012 : 7th international conference : Hradec Králové, November 20-23, 2012 ISSN: 2101 6275 ISBN: 978-80-7372-912-7 